\title{
IDENTIFICATION OF THE HYDROGEOCHEMICAL PROCESSES IN GROUNDWATER OF GLEYSOLS AND RETISOLS TOPOSEQUENCE OF THE OPALENICA PLAIN
}

\author{
Michał Kozłowski', Jolanta Komisarek ${ }^{1}$ \\ 1 Department of Soil Science and Land Reclamation, Poznan University of Life Sciences, Wojska Polskiego 28, \\ 60-637 Poznań, e-mail: mkozl@up.poznan.pl; jolakom@up.poznan.pl
}

Received: 2015.12 .22

Accepted: 2016.03.04

Published: 2016.04.01

\begin{abstract}
Hydrogeochemical investigation was carried out in the toposequence of Gleysols and Retisols within the Opalenica Plain. Groundwater samples from the study area were collected every two or four weeks from 2002 to 2006 in pre-cleaned 1-L polyethylene bottle from 2 representative wells. The results of research indicated that the quantity of dissolved components in groundwater was connected with wells location in the relief and the properties of soil parent materials. The groundwater of soil located higher in the slope (Retisols) was characterized by smaller concentrations of the analysed components, when compared with the composition of groundwater from lower sites of the slope (Gleysols). The groundwater chemistry is mainly controlled by weathering of carbonate minerals as well as silicate weathering. Moreover, the research results indicate that evaporation process can influence the chemical composition of groundwater in the lower part of the slope.
\end{abstract}

Keywords: groundwater chemistry, toposequence, Gleysols, Retisols.

\section{INTRODUCTION}

Many processes and factors, in particular the geochemical reactions, which take place along the direction of flow, have important impact on the chemistry of the groundwater, therefore, groundwater chemistry is a variable feature in both time and space. At each site, groundwater has different and unique chemistry as a result of a number of processes shaping it, like soil/rockwater interaction during recharge and groundwater flow, prolonged storage in the aquifer, dissolution of mineral species, oxidation-reduction reactions, anthropogenic activities and etc. [Todd, 1980,Hem, 1991, Rao, 2002, Naik et al., 2009, Kozlowski and Komisarek, 2013; Kozłowski et al., 2012].

In recent years, the assessment of groundwater chemistry and identification of various hydrogeochemical processes that significantly affect the groundwater quality, has been made with a variety of graphical methods and interpretations of various indicators [Kumar et al., 2006, Raju, 2007; Raju et al., 2011, Apadaca et al., 2007].

In the present study, an attempt was made to identify the major hydrogeochemical processes that control shallow groundwater chemistry in the toposequence of ground moraine of the Poznań Lakeland (west Poland). Hydrogeochemical tools were applied to investigate the properties of groundwater geochemistry at the sampling sites.

\section{MATERIALS AND METHODS}

\section{Study area}

The study was carried out in the municipality Granowo on arable land in the south-central part of the Poznań Lakeland, within Opalenica Plain (Figure 1). This area is a part of a flat ground moraine of the Poznan Phase of Baltic Glaciation. In these geomorphological conditions the Retisols/Luvisols and the Phaeozems/Chernozems/ 
Gleysols form characteristic soil sequences along slopes (toposequence).

\section{Groundwater sampling and analysis}

Groundwater samples from the study area were collected every two or four weeks from 2004 to 2006 in pre-cleaned 1-L polyethylene bottle from the 2 representative wells located over the toposequence. The wells were located in the Mollic Reductigleyic Eutric Gleysols (Aric, Loamic) (GA1 well) and in the Albic Glossic Retisols (Aric, Arenic, Oxyaquic) (GA2 well) (Figure 1). Water samples were collected after pumping out water for about $10 \mathrm{~min}$ to remove stagnate water from the well. Temperatures, $\mathrm{pH}$ and electrical conductivity (EC) were measured in the field, using digital instruments. Then the samples were analysed for calcium, magnesium, potassium and sodium using AAS methods; phosphate using UV/visible spectrophotometer; alkalinity $\left(\mathrm{HCO}_{3}^{-}+\mathrm{CO}_{3}^{2-}\right)$ by the titration technique, Chloride $(\mathrm{Cl})$ was determined by titrating against $\mathrm{AgNO}_{3}$ standard solution and sulphate as barium sulphate using gravimetric method. The total dissolved solids (TDS) were estimated by the calculation method after Hem [1991].

\section{RESULTS AND DISSCUTION}

\section{Soils of toposequence}

The analysis of variability of soils analysed was carried out on the basis of homogeneous natural soil cartographic units [Systematyka gleb Polski, 2011]. In Granowo transect, the following soil unit were distinguished: PWspgl - (Albic Luvisols (Arenic) with glossic properties, PAt Albic Glossic Retisols (Loamic), PAsp - Albic Glossic Retisols (Aric, Arenic), PAspgg - Albic Glossic Retisols (Aric, Arenic, Oxyaquic), PWsggl - Albic Luvisols (Aric, Arenic, Stagnic) with glossic properties, PWgggl - Albic Luvisols (Aric, Loamic, Stagnic) with glossic properties and CZgg - Mollic Reductigleyic Eutric Gleysols (Aric, Loamic) (Figure 1). In the soils classified as the CZgg and PAspgg, the wells were installed, GA1 and GA2, respectively. In the Mol-

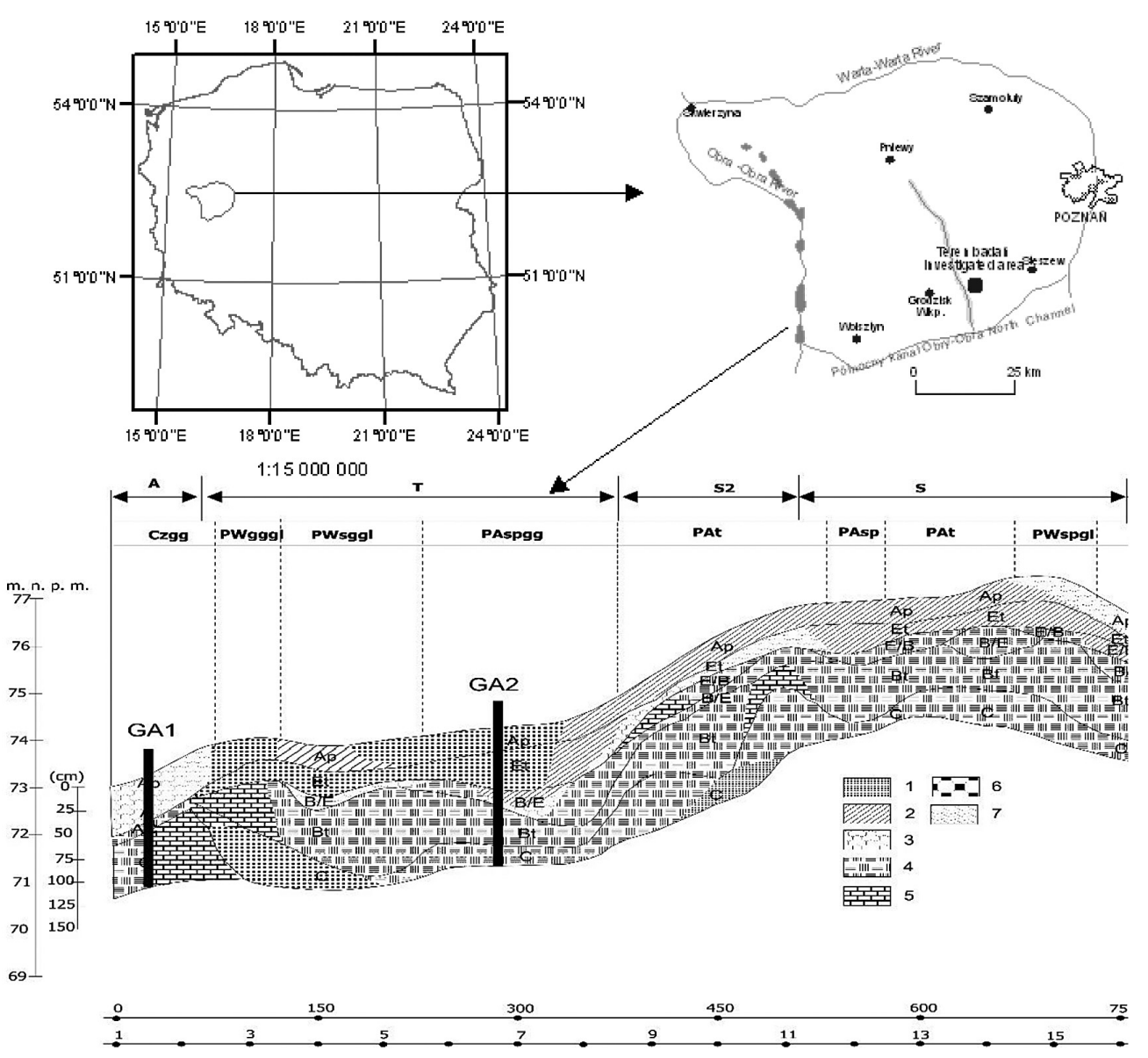

Figure 1. Location of investigated area and distribution of wells in the toposequence: $\mathrm{S}$ - summit, S2 - shoulder, T - pediment, A - footslope, CZ - Gleysols, PW - Luvisols, PA - Retisols 
lic Reductigleyic Eutric Gleysols (Aric, Loamic) unit (CZgg) the average content of organic carbon in $50 \mathrm{~cm}$ thickness of mollic horizonis was $2.3 \%$. The underlying horizons have greyish olive colour. A characteristic feature of this soil unit is the absence of free carbonates in $100 \mathrm{~cm}$ thickness, which would suggest that this soils should be classified to another subtype of Gleysols or Phaeozems. But the alkalinity of the whole solum, high organic carbon content, high thickness of Mollic horizon and underlying horizons with reductimorphic colours have argued the classification of these soils to the mollic Reductigleyic Eutric Gleysols subtype. Within the pediments of the slopes PAspgg soils have formed. In terms of WRB [2014] they belong to a subtype of Albic Retisols (Arenic), like the PAsp soils unit, but in the former soil unit reductimorphic features increases with depth. Sandy texture occurs to an average depth of $64 \mathrm{~cm}$, an average thickness of Ap horizonis $34 \mathrm{~cm}$, while glossic horizon thickness is $40 \mathrm{~cm}$. The Ap surface horizon contains $0.81 \%$ of organic carbon on average.

\section{Groundwater level and general hydrochemistry}

In the well located in the Albic Glossic Retisols (Aric, Arenic, Oxyaquic) the average groundwater table depth was $268 \mathrm{~cm}$ below surface level and $176 \mathrm{~cm}$ below surface level in the well located in the Mollic Reductigleyic Eutric Gleysols (Aric, Loamic) (Table 1). The lower the position of wells in slope, the smaller the depths and fluctuations of groundwater level.

In groundwater of GA2 well, the mean value of the electrical conductivity was $1.31 \mathrm{dS} \cdot \mathrm{m}^{-1}$, while in groundwater at the foot slope (GA1) this value was much higher, $4.44 \mathrm{dS} \cdot \mathrm{m}^{-1}$ (Table 1 ). The $\mathrm{pH}$ values of the investigated groundwater ranged from 7.71 (GA2) to 7.76 (GA1). The aver- age calcium content was from 4.34 (GA2) to 8.28 (GA1) meq $\cdot \mathrm{dm}^{-3}$. Besides calcium ion, the magnesium cation was also present in large quantities. The average concentration of $\mathrm{Mg}^{2+}$ in the water of GA1 was from two to three times higher (6.31 meq $\cdot \mathrm{dm}^{-3}$ ) compared with that determined for the groundwater from the well located in higher part of the slope (1.16 meq $\mathrm{dm}^{-3}$ for GA2). As far as the content of potassium is concerned, it was the highest in the water of GA1, in which the average content was $0.86 \mathrm{meq} \cdot \mathrm{dm}^{-3}$. In the GA2 well, the average concentrations of this ion was 0.14 $\mathrm{meq} \cdot \mathrm{dm}^{-3}$. The amounts of sodium in the analysed groundwater samples were characterized by large disparities.

\section{Hydrogeochemical processes}

There is no single widely accepted method for classification of water types according to their major ion composition. Therefore, in this study the Upchurch [1992] and the Frazee [1982] classifications were used to prepare the Piper diagrams. As follows from the Piper plot, the groundwater samples studied can be classified into various chemical types (Figure 2). In the water samples from GA1 well the dominant hydrochemical types are Mixed(cation) - Mixed(anion) (38\%), Mixed(cation) $-\mathrm{HCO}_{3}, \mathrm{Cl}(23 \%)$ and Mixed(cation) $-\mathrm{HCO}_{3}(13 \%)$, in the samples from $\mathrm{GA} 2$ well $-\mathrm{Ca}-\mathrm{HCO}_{3}(92 \%)$ and $\mathrm{Ca}, \mathrm{Mg}-$ $\mathrm{HCO}_{3}(8 \%)$. In addition to the Piper diagram, Gibbs plots were used to establish the relationship of water composition and aquifer lithological characteristics [Gibbs 1970]. The data points of the area on the Gibbs' diagram in Figure 3 suggest chemical weathering of rock-forming minerals as the origin of the ions. In some water samples from GA1, evaporation could affect the amount of dissolved components. However, the data for a few samples falling in the evaporation zone suggest

Table 1. The average values of chemical composition of analysed groundwater

\begin{tabular}{|c|c|c|c|c|c|c|c|c|c|c|}
\hline \multirow{2}{*}{$\begin{array}{l}\text { Wells } \\
\text { number }\end{array}$} & \multirow{2}{*}{$\begin{array}{c}\mathrm{EC} \\
\mathrm{dS}^{*} \mathrm{~m}^{-1}\end{array}$} & \multirow{2}{*}{$\begin{array}{c}\mathrm{pH} \\
\text { units }\end{array}$} & $\mathrm{HCO}_{3}^{-}$ & $\mathrm{SO}_{4}^{2-}$ & $\mathrm{Cl}^{-}$ & $\mathrm{Ca}^{2+}$ & $\mathrm{Mg}^{2+}$ & $\mathrm{K}^{+}$ & $\mathrm{Na}^{+}$ & \multirow{2}{*}{$\begin{array}{c}\text { ZWG } \\
\text { cm p.p.t. }\end{array}$} \\
\hline & & & \multicolumn{7}{|c|}{$\mathrm{meq}^{*} \mathrm{dm}^{-3}$} & \\
\hline \multirow{3}{*}{ GA1 } & 4.44 & 7.76 & 15.76 & 5.76 & 8.62 & 8.28 & 6.31 & 0.86 & 4.33 & 176 \\
\hline & 2.03 & 6.93 & 5.28 & 0.99 & 4.21 & 2.11 & 1.43 & 0.24 & 1.87 & 75 \\
\hline & 6.52 & 8.57 & 38.30 & 10.62 & 16.83 & 14.29 & 10.93 & 2.48 & 6.54 & 216 \\
\hline \multirow{3}{*}{ GA2 } & 1.31 & 7.71 & 5.02 & 1.25 & 0.24 & 4.34 & 1.16 & 0.14 & 0.33 & 268 \\
\hline & 0.71 & 7.22 & 0.80 & 0.25 & 0.03 & 2.19 & 0.67 & 0.06 & 0.02 & 163 \\
\hline & 2.39 & 8.54 & 13.4 & 3.58 & 0.78 & 5.49 & 2.00 & 0.35 & 0.69 & 315 \\
\hline
\end{tabular}

average

minimum

maximum 


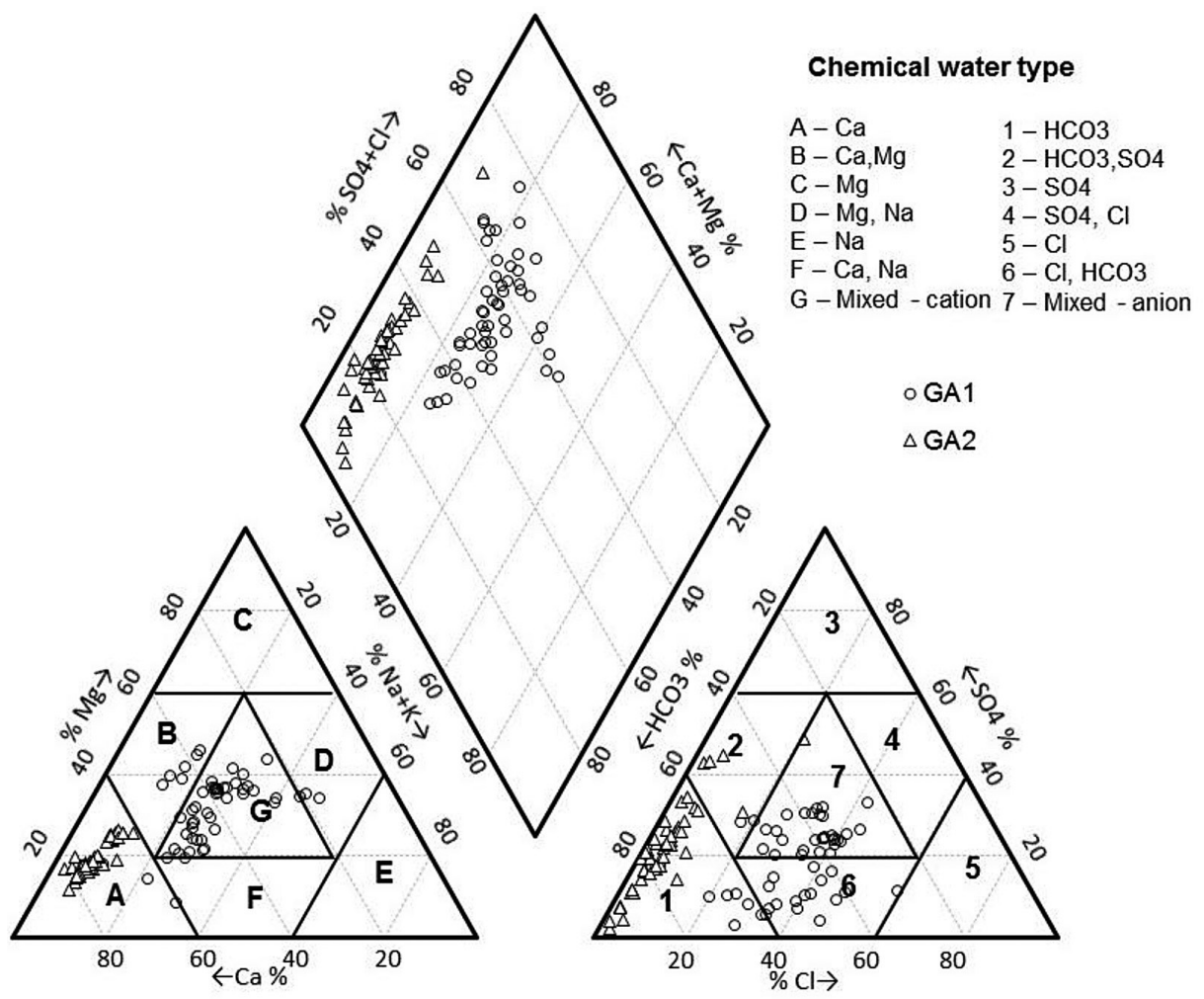

Figure 2. Piper trilinear diagram indicating the groundwater type

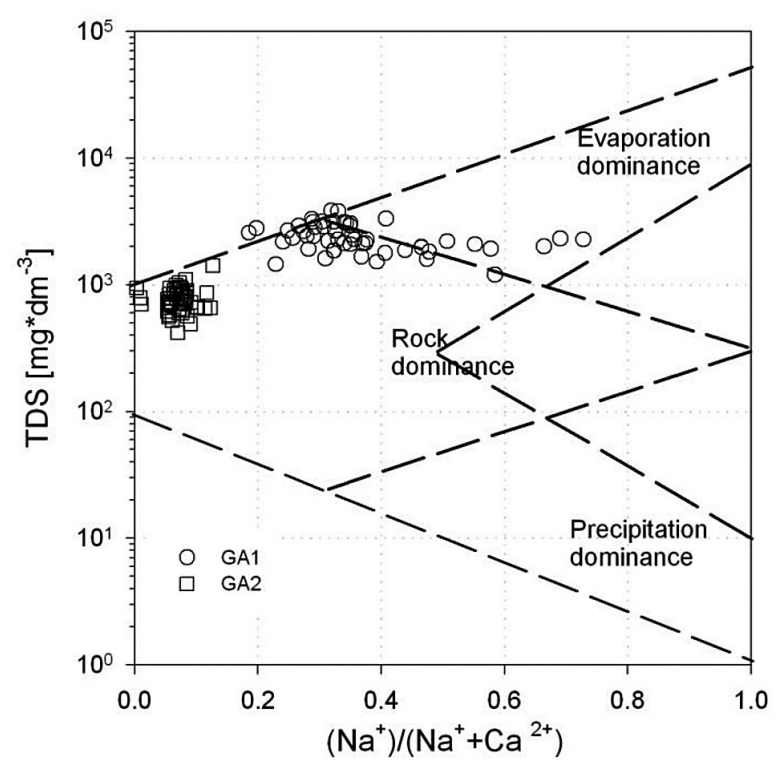

Figure 3. Gibbs plot showing geochemical processes in groundwater of the study area

that surface contamination sources, for example fertilization, seem to affect the groundwater quality in the region studied.

\section{Carbonate weathering and dissolution}

Calcium and magnesium are the dominant ions among the cations present in groundwater. Similarly, bicarbonate is also present in sig- nificant amounts. Carbonate rich rocks such as a glacial till and glacifluvial clay, are the main source of carbonate weathering. In $\mathrm{Ca}^{2+}+\mathrm{Mg}^{2+}$ versus alkalinity $+\mathrm{SO}_{4}^{2-}$ scatter diagram (Figure 4A), the majority of samples occur along and above the equiline, indicating that dissolutions of carbonates and sulphate minerals and silicate weathering were the primary processes leading to $\mathrm{HCO}_{3}{ }^{-}+\mathrm{SO}_{4}{ }^{2-}$ accumulation in groundwater [Cerling et al., 1989; Datta and Tyagi, 1996; Fisher and Mullican, 1997]. The points corresponding to a few samples are positioned on the $\mathrm{Ca}^{2+}+\mathrm{Mg}^{2+}$ side, which indicates that these ions derived from other processes, such as the reverse ion exchange reaction. Moreover, if the $\mathrm{Ca}^{2+}$ and $\mathrm{Mg}^{2+}$ were derived exclusively from carbonates and silicate weathering, their presence should be balanced by alkalinity alone. In the area in which $\mathrm{Ca}^{2+}$ and $\mathrm{HCO}_{3}{ }^{-}$come only from calcite weathering, the ratio of $\mathrm{Ca}^{2+}$ to $\mathrm{HCO}_{3}{ }^{-}$is $1: 2$, while in the area in which they are from dolomite weathering, it is 1:4 [Garrels and Mackenzie, 1971; Holland, 1978; Subramani et al., 2010]. In the plot of $\mathrm{Ca}^{2+}$ content vs alkalinity (Figure 4B), points indicate that the calcite weathering is the process that occurs in the soils analysed. Das and Kaur [2001] have reported that if the calcium and sulphate in water originate from weathering of gypsum and anhydrite, the $\mathrm{Ca}^{2+} / \mathrm{SO}_{4}{ }^{2-}$ ratio is $1: 1$. The majori- 

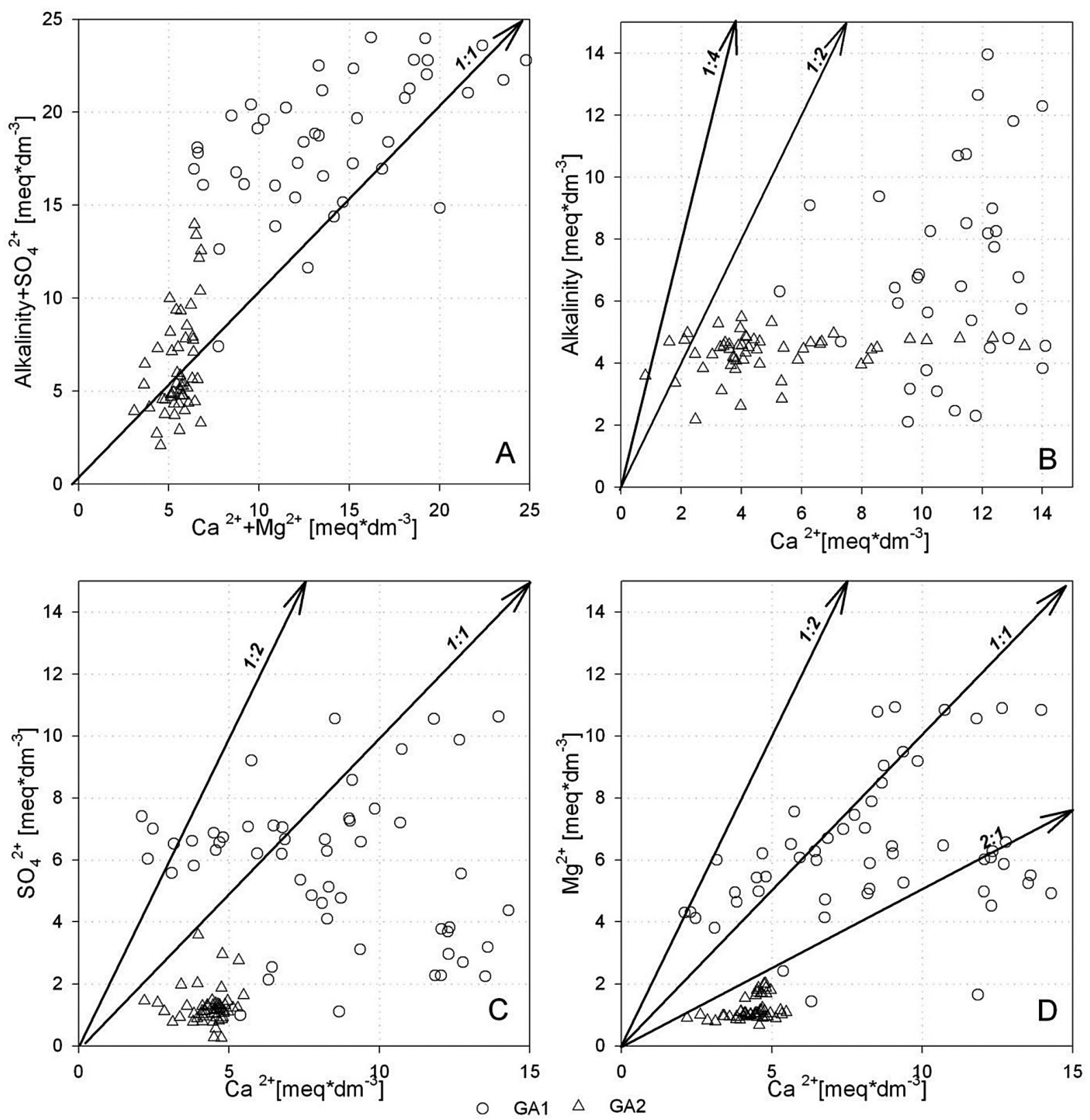

Figure 4. Relations between content of $\mathrm{Ca}, \mathrm{Mg}, \mathrm{SO}_{4}$ and alkalinity in the groundwater

ty of the groundwater samples show an excess of calcium over sulphate, and a few samples follow along the 1:1 equiline (Figure 4C). This clearly indicates the dominance of calcite weathering in the presence of sulphuric acid, over the dolomite weathering [Garrels and Mackenzie, 1971]. Excess of sulphate over calcium in samples from GA1 water wells is the evidence of the removal of calcium from the system, likely by calcite precipitation or weathering of magnesium sulphate minerals. Mayo and Loucks [1995] have explained that if the $\mathrm{Ca}^{2+} / \mathrm{Mg}^{2+}$ molar ratio is equal to one, dissolution of dolomite should occur, whereas the above ratio higher than one is indicative of greater calcite contribution. More- over, the $\mathrm{Ca}^{2+} / \mathrm{Mg}^{2+}$ molar ratio higher than two, indicates dissolution of silicate minerals, which provide calcium and magnesium to groundwater [Katz et al., 1998]. In $\mathrm{Ca}^{2+}+$ versus $\mathrm{Mg}^{2+}$ scatter diagram (Figure 4D), all values from GA2 and a few results from GA1 are placed near 1:1 line, pointing out that dissolution of calcite is the dominant geochemical process followed by dissolution of dolomite and silicate minerals. The majority of points corresponding to the samples from GA1 well show an excess of magnesium over calcium, which could be a result of water interaction with $\mathrm{Mg}$-rich silicate minerals as additional process to dissolution of dolomite [Hem, 1991]. 


\section{Silicate weathering}

Silicate weathering is one of the key geochemical processes which control the groundwater chemistry [Garrels and Mackenzie, 1967]. Quantification of the products of silica weathering is more difficult because the disintegration of silicates is incongruent, generating a variety of solid phases [Das and Kaur, 2001]. Silicate weathering can be described by estimating the ratio between $\mathrm{Na}^{+}+\mathrm{K}^{+}$and total cations (TZ+). On the plot of $\mathrm{Na}^{+}+\mathrm{K}$ versus $\mathrm{TZ}+$, the majority of points corresponding to the groundwater samples occur above the 1:2 line showing less silicate (alkali feldspar) weathering (Figure 5A). Only a few results of GA1 samples are close to the 1:2 equiline, which can indicate the involvement of silicate weathering in the geochemical processes [Sarin et al., 1989; Stallard and Edmond, 1983]. In $\mathrm{Ca}^{2+}+\mathrm{Mg}^{2+}$ vs. total cations (TZ+) scatter diagram (Figure 5B), the majority of points corresponding to the samples from GA2 well occur along the equiline $1: 1$. It indicates that these ions $\left(\mathrm{Ca}^{2+}+\mathrm{Mg}^{2+}\right)$ have originated from the weathering of calcium and magnesium rich minerals. Points assigned to the samples from GA1 well are close to the 1:0.7 line pointing out that silicate weathering occurs in additional to the carbonate dissolution [Subramani et al., 2010].

\section{lon exchange}

Ion exchange is one of important processes responsible for the concentration of ions in

groundwater. Schoeller [1965, 1967] suggested two Chloro-Alkaline Indices CAI-1 and CAI-2 for the interpretation of ion exchange between groundwater and the environment:

$$
\begin{gathered}
\mathrm{CAI}-1=\mathrm{Cl}^{-}-\left(\mathrm{Na}^{+}+\mathrm{K}^{+}\right) / \mathrm{Cl}^{-} \\
\mathrm{CAI}-2=\mathrm{Cl}^{-}-\left(\mathrm{Na}^{+}+\mathrm{K}^{+}\right) /\left(\mathrm{SO}_{4}{ }^{2-}+\mathrm{HCO}_{3}^{-}+\right. \\
\left.+\mathrm{CO}_{3}{ }^{2-}+\mathrm{NO}_{3}^{-}\right)
\end{gathered}
$$

All values are expressed in meq/l. Positive Chloro-Alkaline Indices indicate exchange of $\mathrm{Na}$ and $\mathrm{K}$ from the water with $\mathrm{Mg}$ and $\mathrm{Ca}$ from the rocks, while the negative indices inform that there is an exchange of $\mathrm{Mg}^{2+}$ and $\mathrm{Ca}^{2}$ from the water with $\mathrm{Na}^{+}$and $\mathrm{K}^{+}$from the rocks [Schoeller, 1965]. CAI-1 and CAI-2 values for the water samples from GA1 wells studied are positive (Figure 6). This observation indicates the dominance of ionexchange of $\mathrm{Na}^{+}$and $\mathrm{K}^{+}$in the water with $\mathrm{Mg}^{2+}$ and $\mathrm{Ca}^{2+}$ in the aquifer material. The majority of points corresponding to the samples from GA2 well have negative values of CAI-1 and CAI-2, which can indicate the ion-exchange of $\mathrm{Mg}^{2+}$ and $\mathrm{Ca}^{2+}$ in the water with $\mathrm{Na}^{+}$and $\mathrm{K}^{+}$in the aquifer material. Moreover, if ion exchange is the dominant process, the data points of the plot of $\mathrm{Ca}^{2+}$ $+\mathrm{Mg}^{2+}$ versus $\mathrm{HCO}_{3}{ }^{-}+\mathrm{SO}_{4}{ }^{2-}$ tend to shift to the right due to the excess of $\mathrm{HCO}_{3}^{-}+\mathrm{SO}_{4}{ }^{2-}$. If the dominant process is the reverse ion exchange, the points are shifted to the left due to a large excess of $\mathrm{Ca}^{2+}+\mathrm{Mg}^{2+}$ over $\mathrm{HCO}_{3}{ }^{-}+\mathrm{SO}_{4}{ }^{2-}$. In $\mathrm{Ca}^{2+}+\mathrm{Mg}^{2+}$ versus alkalinity $+\mathrm{SO}_{4}{ }^{2-}$ scatter diagram (Figure $4 \mathrm{~A})$, the majority of points assigned to the samples studied occur above and along the equiline,
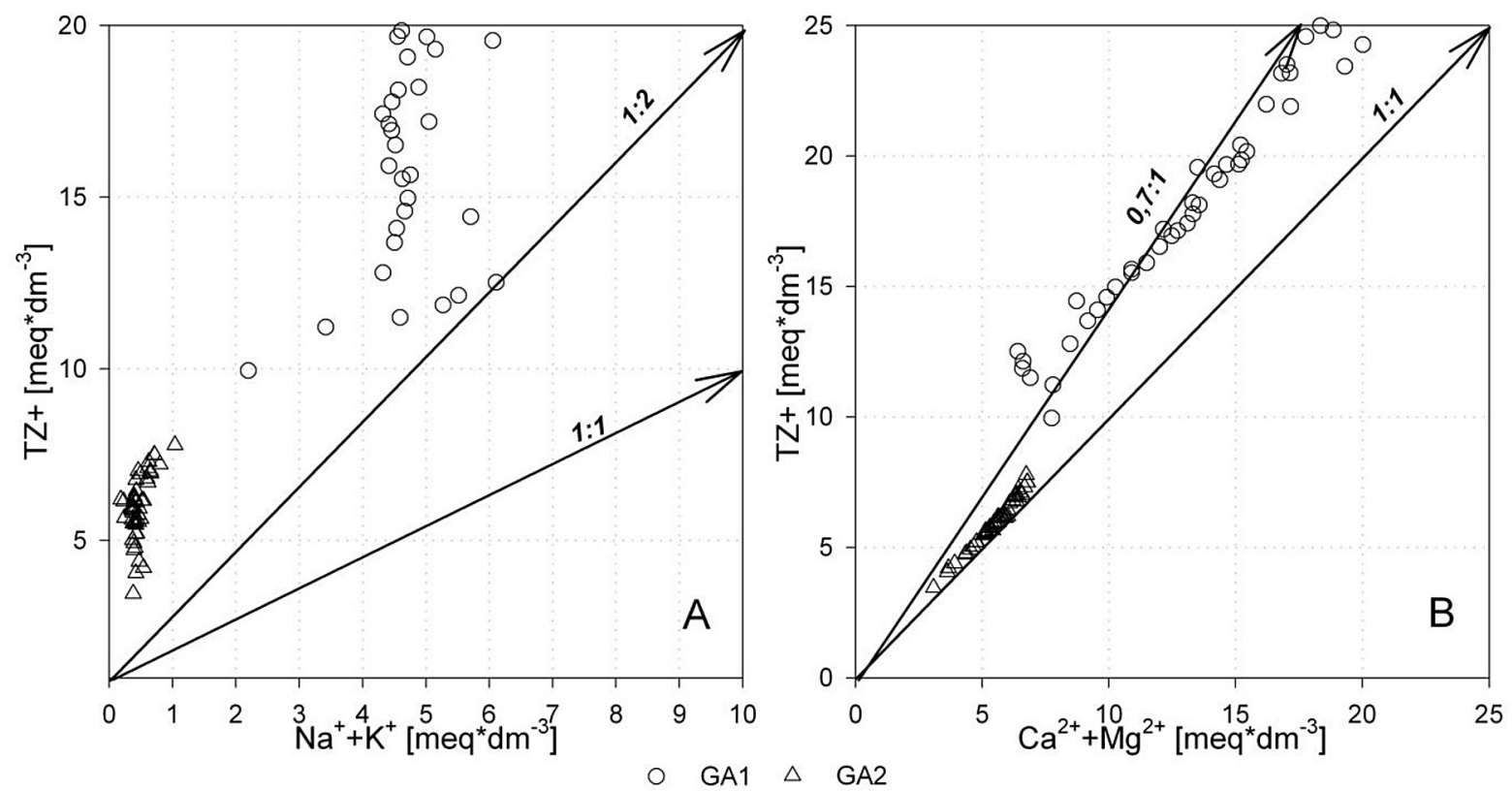

Figure 5. Relation between total cation, $\mathrm{Na}+\mathrm{K}$ and $\mathrm{Ca}+\mathrm{Mg}$ in the study groundwater 


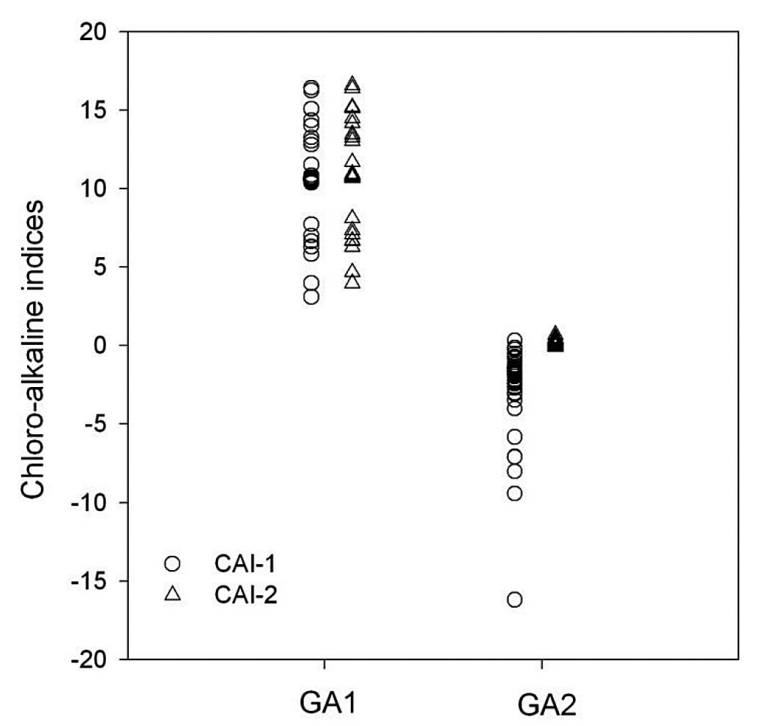

Figure 6. Chloro-alkaline indices indicating ion exchange process

pointing out that the ion exchange is the dominant process against the reverse-ion exchange.

\section{Evaporation}

The evaporation processes would cause an increase in the concentration of all ions in groundwater. A constant value of $\mathrm{Na} / \mathrm{Cl}$ on increasing $\mathrm{EC}$ is an indicator of an evaporation dominant environment [Jankowski and Acworth, 1997]. The plot of $\mathrm{Na}^{+} / \mathrm{Cl}^{-}$ratio versus EC (Figure 7) shows that evaporation is not the major process in this area. In most samples with decreasing values of the ratio of $\mathrm{Na} / \mathrm{Cl}$ increases the $\mathrm{EC}$, which may be associated with removal of sodium from water by

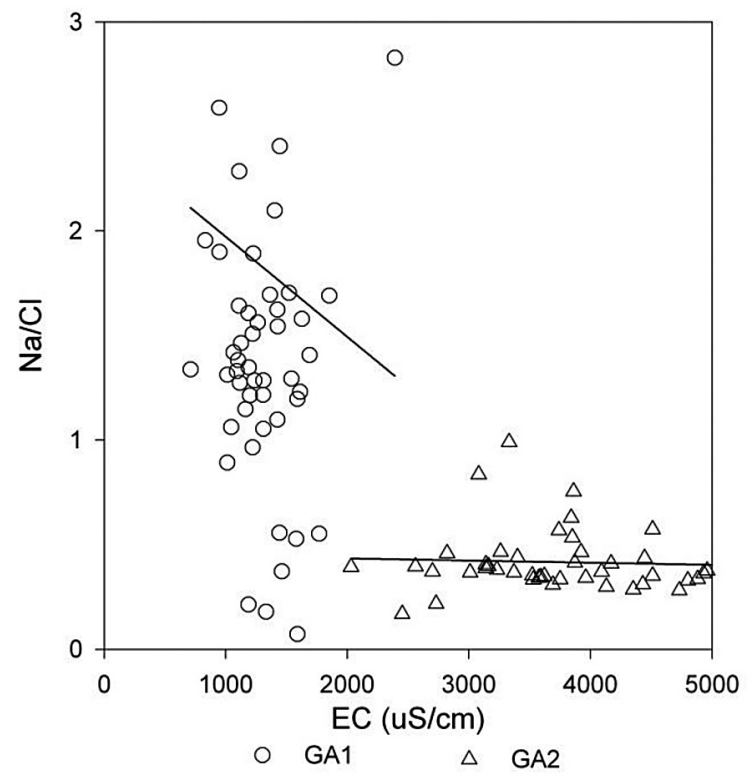

Figure 7. Relation between $\mathrm{EC}$ and $\mathrm{Na} / \mathrm{Cl}$ in the groundwater ion exchange [Rajmohan and Elango, 2004, Zhu et al., 2008]. However, weathering of sodium silicates process $(\mathrm{Na} / \mathrm{Cl}>1)$ can occur mainly in the groundwater from GA1 well [Meybeck, 1987].

\section{CONCLUSION}

Evaluation of soil groundwater chemistry and hydrogeochemical processes in the toposequence of the Poznan Lakeland permits drawing the following conclusions:

1. The groundwater of soil located higher in the toposequence was characterized by smaller concentrations of the components analysed, when compared with the composition of water from lowest sites on the slope.

2. In the groundwater samples from Albic Glossic Retisols (Aric, Arenic, Oxyaquic) well the dominant hydrochemical types was the calcium bicarbonate hydrochemical type, while in groundwater from Mollic Reductigleyic Eutric Gleysols (Aric, Loamic) the mixed hydrochemical type.

3. The water chemistry of the toposequence analysed is mainly controlled by the products of weathering of parent materials and minerals, mainly carbonates, then silicates. In the case of Mollic Reductigleyic Eutric Gleysols (Aric, Loamic), evaporation process can influence the chemical composition of groundwater in the lower part of the toposequence.

\section{REFERENCES}

1. Apadaca L.E., Jeffrey B.B., Michelle C.S., 2007. Water quality in shallow alluvium aquifers. Upper Colorado river basin Colorado. Journal of the American Water Resources Association 38(1), 133-148.

2. Cerling T.G., Pederson B.L., Von Damm K.L, 1989. Sodium-calcium ion exchange in the weathering of shales: Implications for global weathering budgets. Geology (17), 552-554.

3. Das B.K., Kaur P., 2001. Major ion chemistry of Renuka lake and weathering processes, Sirmaur district, Himachal Pradesh, India. Environmental Geology 40(7), 908-917.

4. Datta P.S., Tyagi S.K., 1996. Major ion chemistry of groundwater in Delhi area: chemical weathering processes and groundwater flow regime. Geological Society of India 47(2), 179-188.

5. Fisher R.S., Mullican W.F., 1997. Hydrochemical evolution of sodium-sulfate and sodium-chloride groundwater beneath the Northern Chihuahuan 
Desert, Trans-Pecos, Texas, USA. Hydrogeology Journal 5(2), 4-16.

6. Frazee J.M., 1982. Geochemical pattern analysis: method of describing the Southeastern Limestone regional aquifer system. Studies of Hydrogeology of the Southeastern United States, Special Publications (1), 46-58.

7. Garrels R.M., Mackenzie F.T., 1967. Origin of the chemical compositions of some springs and lakes. Equilibrium concepts in natural water systems 67 , 222-242.

8. Garrels R.M., Mackenzie F.T., 1971. Evolution of sedimentary rocks. 1st ed. ed. Norton, New York, xvi, 397.

9. Hem J.D., 1991. Study and interpretation of the chemical characteristics of natural water. United States Geological Survey Water-Supply Paper 2254. Scientific Publishers.

10. Holland H.D., 1978. The chemistry of the atmosphere and oceans. Wiley, New York.

11. Jankowski J., Acworth R.I., 1997. Impact of debris-flow deposits on hydrogeochemical processes and the developement of dryland salinity in the Yass River catchment. New South Wales, Australia. Hydrogeology Journal 5 (4), 71-88.

12. Katz B.G., Catches J.S., Bullen T.D., Michel R.L., 1998. Changes in the isotopic and chemical composition of ground water resulting from a recharge pulse from a sinking stream. Journal of Hydrology 211(1), 178-207.

13. Kozlowski M., Komisarek J., 2013. Temporal variability of selected dissolved components content in groundwater of the catena system of Poznan Lakeland. Annual Set The Environment Protection 15, 1965-1981.

14. Kozłowski M., Komisarek J., Wiatrowska K., 2012. Chemical speciation of selected dissolved components of groundwater in the catena of the Poznań Lakeland. Annual Set The Environment Protection 14, 607-622.

15. Kumar M., Ramanathan A.L., Rao M.S., Kumar B., 2006. Identification and evaluation of hydrogeochemical processes in the groundwater environment of Delhi, India. Environmental Geology 50(7), 1025-1039.

16. Mayo A.L., Loucks M.D., 1995. Solute and isotopic geochemistry and ground water flow in the central Wasatch Range, Utah. Journal of Hydrology 172(1), 31-59.

17. Meybeck M., 1987. Global chemical weathering of surficial rocks estimated from river dissolved loads. American Journal of Science (287), 401-428.

18. Naik P.K., Awasthi A.K., Anand A., Behera P.N., 2009. Hydrogeochemistry of the Koyna River basin, India. Environmental Earth Sciences 59(3), 613-629.
19. Rajmohan N., Elango L., 2004. Identification and evolution of hydrogeochemical processes in the groundwater environment in an area of the Palar and Cheyyar River Basins, Southern India. Environmental Geology 46(1), 47-61.

20. Raju N.J., 2007. Hydrogeochemical parameters for assessment of groundwater quality in the upper Gunjanaeru River basin, Cuddapah District, Andhra Pradesh, South India. Environmental Geology 52(6), 1067-1074.

21. Raju N.J., Shukla U.K., Ram P., 2011. Hydrogeochemistry for the assessment of groundwater quality in Varanasi: a fast-urbanizing center in Uttar Pradesh, India. Environmental monitoring and assessment 173(1-4), 279-300.

22. Rao N.S., 2002. Geochemistry of groundwater in parts of Guntur district, Andhra Pradesh, India. Environmental Geology 41(5), 552-562.

23. Sarin M.M., Krishnaswami S., Dilli K., Somayajulu B.L., Moore W.S., 1989. Major ion chemistry of the Ganga-Brahmaputra river system: Weathering processes and fluxes to the Bay of Bengal. Geochimica et cosmochimica acta 53(5), 997-1009.

24. Schoeller H., 1965. Hydrodynamicue lans lekarst. Actes du Colloque de Dubrovnik, IAHS/ UNESCO, Paris, 2-20.

25. Schoeller H., 1967. Qualitative evaluation of groundwater resources (In methods and techniques of Groundwater Investigation and Development). Water Resource Series, UNESCO, Paris (33), 44-52.

26. Stallard R.F., Edmond J.M., 1983. Geochemistry of the Amazon: 2. The influence of geology and weathering environment on the dissolved load. Journal of Geophysical Research: Oceans (19782012) 88 (C14), 9671-9688.

27. Subramani T., Rajmohan N., Elango L., 2010. Groundwater geochemistry and identification of hydrogeochemical processes in a hard rock region, Southern India. Environmental monitoring and assessment 162(1-4), 123-137.

28. Systematyka gleb Polski, 2011. wyd. 5. Roczniki gleboznawcze 62(3), 5-142.

29. Todd D.K., 1980. Groundwater: Hydrolohy, 2nd Edition, John Willey and Sons, pp. 315.

30. Upchurch S.B., 1992. Quality of water in Florida's aquifer systems. Florida's Ground Water Quality Monitoring Program: Tallahassee, FL, Florida Geological Survey, 12-51.

31. World reference base for soil resources 2014. International soil classification system for naming soils and creating legends for soil maps. FAO, Rome, Online-Ressource.

32. Zhu G.F., Su Y.H., Feng Q., 2008. The hydrochemical characteristics and evolution of groundwater and surface water in the Heihe River Basin, northwest China. Hydrogeology Journal 16(1), 167-182. 